\title{
Prognostic Factors in Advanced Ovarian Cancer - A Clinical Trial
}

\author{
Alexandra Ligia Dinca ${ }^{1}$, Rodica Daniela Birla ${ }^{2,3}$, Valeriu Gabi Dinca ${ }^{4}$, Cristian Marica ${ }^{2,3}$, Eugenia Panaitescu ${ }^{5}$, \\ Silviu Constantinoiu ${ }^{2,3}$
}

'Medicover Hospital Bucharest, Romania

${ }^{2}$ Carol Davila University of Medicine and Pharmacy, Bucharest, Romania

${ }^{3}$ General and Esophageal Surgery Department, Center of Excellence in Esophageal Surgery, Sf. Maria Clinical Hospital, Bucharest

${ }^{4}$ Titu Maiorescu University Bucharest, Romania

${ }^{5}$ Medical Biostatistic Department, Carol Davila University of Medicine and Pharmacy, Bucharest, Romania

Corresponding author:

Rodica Birla, MD

General and Esophageal Surgery

Department, Center of Excellence

in Esophageal Surgery, Sf. Maria

Clinical Hospital, Bucharest, Romania

E-mail: birlarodica@ahoo.com

\section{Rezumat}

Factori de prognostic în cancerul de ovar avansat - un trial clinic

Introducere: Cancerul ovarian reprezintă cea mai letală afecțiune onco-ginecologică. Marea majoritate a pacientelor se diagnostichează în stadii avansate de boală, în care rata recidivelor este crescută, iar şansa de supraviețuire la 5 ani este sub $45 \%$.

Scopul: evaluarea unor corelații ale supraviețuirii globale cu caracteristici clinico paraclinice, tumorale sau de tratament pentru identificarea factorilor de prognostic, la pacientele cu cancer ovarian avansat - stadiile III şi IV FIGO.

Material şi Metodă: Am efectuat o analiză retrospectivă la 65 paciente cu cancer ovarian avansat - stadiile III şi IV FIGO operate în perioada 2010-2018, cu o perioadă de urmărire de cel puțin un an. S-au efectuat corelații cu caracteristici clinicoparaclinice, tumorale sau de tratament cu supraviețuirea globală. Rezultate: În analiza statistică univariată de supraviețuire se obține o asociere semnificativă statistică cu prezența durerilor pelvine la internare ( $p \_$value $\left.=0.033744\right)$, in cadrul substadiului III (p_value = 0.007595 , respectiv p_value $=0.022090$ ), cu tipul de citoreducție (p_value $=0.035554)$, cu complicatiile postoperatorii $\left(\mathrm{p} \_\right.$value $=$ $0.000685)$ in cadrul subtipurilor histopatologice ( $\left.p \_v a l u e=0.046266\right)$, $\mathrm{cu}$ tratamentul adjuvant $\left(\mathrm{p} \_\right.$value $=0.000083$ ). Analiza de regresie multivariata Cox a arătat că chimioterapia adjuvantă $(\mathrm{HR}=0.046$, $95 \% \mathrm{CI}=(0.008,0.261),\left(\mathrm{p} \_\right.$value $\left.=0.000492\right)$, citoreducția suboptimală $\left(\mathrm{HR}=0.346,95 \% \mathrm{CI}=(0.140,0.853),\left(\mathrm{p} \_\right.\right.$value $\left.=0.021219\right)$ şi 
complicatiile postoperatorii $\left(\mathrm{HR}=53.751,95 \% \mathrm{CI}=(4.672,618.365)\right.$, $\left(\mathrm{p} \_\right.$value $\left.=0.001389\right)$ sunt factori de prognostic independenți.

Concluzii: Lipsa durerilor pelvine la momentul diagnosticului, stadiul FIGO IIIC, citoreductia suboptimală, prezența complicațiilor postoperatorii, lipsa tratamentul adjuvant şi tipul histopatologic de cancer cu celule clare s-au dovedit factori de prognostic pentru supraviețuirea globală. La pacientele cu cancer ovarian avansat, tipul de citoreducție optimală şi efectuarea tratamentului adjuvant sunt factori de protecție independenți pentru supraviețuirea globală, iar prezența complicațiilor postoperatorii s-a dovedit factor de risc independent.

Cuvinte cheie: cancer ovarian, factori de pronostic, citoreducție chirurgicală

\section{Abstract}

Introduction: Ovarian cancer is one of most fatal gynecological condition. The number of patients diagnosed in advanced stages is very high, hence the recurrence rate is high, and the chance of survival at 5 years is less than $45 \%$.

Purpose: To evaluate correspondance between overall survival with clinical, paraclinical, tumor or treatment characteristics and to identify prognostic factors in patients with advanced ovarian cancer - stage III and IV FIGO.

Material and Method: We performed a retrospective study in 65 patients with advanced ovarian cancer - stages III and IV FIGO operated during 2010-2018, with a follow-up period of at least one year. There were correlations with clinical and paraclinical charateristics, tumor or treatment characteristics and with overall survival.

Results: In the univariate statistical analysis of survival, a significant statistical association is obtained by the presence of pelvic pain at presentation ( $\mathrm{p}$ _value $=0.033744)$, with the stage III ( $p_{\text {_value }}=0.007595$, respectively $\mathrm{p}$ _value $\left.=0.022090\right)$, with the type of citoreduction ( $\mathrm{p}$-value $=$ $0.035)$, with postoperative complications ( $p_{-}$value $\left.=0.000685\right)$ within the pathological subtypes

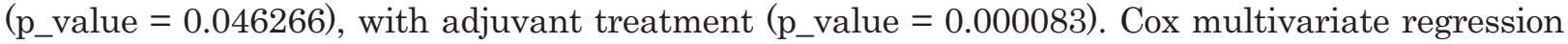
analysis showed that adjuvant chemotherapy $\left(\mathrm{HR}=0.046,95 \% \mathrm{CI}=(0.008,0.261)\right.$, ( $\mathrm{p} \_$value $=$ $0.000492)$, suboptimal cytoreduction $(\mathrm{HR}=0.346,95 \% \mathrm{CI}=(0.140,0.853)$, (p_value $)=0.021219)$ and postoperative complications $(\mathrm{HR}=53,751,95 \% \mathrm{CI}=(4,672,618,365)$, $(\mathrm{p}$ _value $=0.001389)$ are independent prognostic factors.

Conclusions: Absence of pelvic pain at diagnosis, FIGO IIIC stage, suboptimal cytoreduction, presence of postoperative complications, inadequate adjuvant treatment and pathological type of clear cell cancer have been shown to be prognostic factors for overall survival. In patients with advanced ovarian cancer, the type of optimal citoreduction and adjuvant treatment are independent protective factors for overall survival, and the presence of postoperative complications has been shown to be an independent risk factor.

Key words: ovarian cancer, prognostic factors, surgical cytoreduction

\section{Introduction}

Ovarian cancer is one the most fatal gynecological disease. Surgical treatment is one of the most important step in the management of disease, either as a primary treatment or following neoadjuvant chemotherapy. The great majority of patients are diagnosed with progressive of disease, in which the recurrence rate is upraised, and the chance of 
survival at 5 years is below $45 \%$ and for stages III and IV the disease is $25 \%$. (1)

For high-grade serous epithelial ovarian cancer type, median survival period less than 5 years, but for about $15 \%$ of patients it can reach over 7-10 years. Studying the survival analysis, it was observed that in these patients the subsequent prognostic factors were identified: young age, early stage of disease, low-grade or non-serous histo-pathological type, absence of ascites and optimal surgical citoreduction (2).

The main objective of prevention, screening protocols and early stage diagnosis of ovarian tumors are to improve survival and diseasefree interval (3).

Observations of the last 30 years, showed that the incidence of the disease has collapsed mainly because increased utilisation of combined oral contraceptive pills and the decreased administration of postmenopausal HRT (4).

In the USA, the incidence of the disease dropped by $1.9 \%$ annually between 20042013 while the mortality decreased by $2.2 \%$ annually in the same period (5). In France, the prevalence of the disease dropped in the period between 1980-2012 with about $0.6 \%$ per year while mortality decreased by $1.2 \%$ per year (6).

Also, it seems that the mortality in ovarian cancer has declined but it could not be demonstrated that the real cause of this dropping is not in fact the direct correlation with the decrease of the incidence of the disease. Some studies have concluded that because patients with complete cytoreduction have survived longer than those with optimal intervention, this fact demonstrates that the absence of the macroscopic tumor residue is the most important prognostic factor for long-term survival (7). Another important study showed that patients with stage III/IV ovarian cancer who had complete cytoreduction had a 5.5\% increase in the median survival rate, which we can translate by an increase of 2-3 months, compared to the patients who have undergone optimal surgery (8).

Some authors states that, balancing the two main protocols for ovarian tumors treatment, particulary: neoadjuvant chemotherapy followed by cytoreductive surgery versus the other way arround, using the treatment protocol that primary recomands debulking would improve survival by about 5.2 months (9).

Other authors dispute that neoadjuvant chemotherapy increases the chances of optimal cytoreduction, but in terms of long term survival, no statistically significant distinction could be proven between the two distinctive protocols (10).

Regarding the comparison of the use of intraoperative or intraperitoneal postoperative chemotherapy in patients with optimal cytoreduction versus standard chemotherapy as a single treatment in ovarian neoplasm, there was an increase in the survival of 3 years in favor of patients with optimucytoreduction followed by chemotherapy (11).

On one study from 2018 comparing the long-term survival of ovarian cancer patients with other comorbidities: cardiovascular disease, including HTN, showed that patients over 60 years of age with beta-blockers over 1 year had a longer distance survival than those without this cardiac treatment (12).

From a pathological point of view, invasive serous tumors into pelvis are associated with a mortality rate of $34 \%$, while mucinous tumors with up to $50 \%$ (13).

Some authors had analyzed the presence of BRCA 1 and 2 genes on long-term survival and disease-free interval, deducing that patients expressing these genes had better survival compared to rest of the patients (14).

Anyhow in patients with ovarian tumors the 5-year survival rate is boosting due to, most likely, the developement and optimization of treatment (15).

\section{Material and Method}

The study comprise patients treated for with stage III and IV ovarian cancer between 01.01.2010 - 01.11.2018 in the General and Esophageal Surgery department at Sfanta Maria Clinical Hospital, Bucharest. 
Patient data were collected from clinical notes, operating notes, pathological and cytological reports and oncology letters prior to admission. The study included a total of 65 patients. As possible factors with prognostic role in patients with ovarian cancer we analyzed: comorbidities, gynecological surgical background, high blood pressure, diabetes, obesity, clinical factors like age, nulliparous / multiparous status, reproductive status, presence of pelvic pain, metrorrhagia, abdominal distension, paraclinical factors CA 125 marker level at admission, imaging aspects of abdominal-pelvic USS / tomography, radiological aspects of abdominal voids, colonoscopies, tumor characteristics - pathological / cytological examination, histopathological type of postoperative specimens, tumor grading, FIGO stage, presence of tumor recurrence and therapeutic factors.

Preoperative pathological diagnosis was based on ascites fluid cytology obtained by paracentesis or biopsy of abdominal/pelvic tumors by exploratory laparotomy / laparoscopy according to the classic histo-pathological standards for establishing malignancy. The histo-pathological types were divided into 6 classes according to the AJCC (American Joint Commission of Cancer) criteria. The clinical stages of the disease were divided into 4 stages according to FIGO criteria.

Among the therapeutic factors we analyzed the neoadjuvant treatment, type of resection: optimal/suboptimal, type of resection complex /non-complex, postoperative complications and postoperative chemotherapy treatment.

The pre-operative neoadjuvant treatment performed in patients in which the primary surgical treatment was not appropriate consisted of 5-6 cycles of chemotherapy performed 1 month apart, and the most common chemotherapeutic agents used were based on Taxols and Platinum Salts. The surgical treatment aimed for maximum cytoreduction, according to the latest ESMO recommendations. Data from the literature recommend standardization of surgical treatment in ovarian cancer, thus, ovarian cancer surgery can be evaluated as optimal or suboptimal cytoreduction depending on the presence and size of the postoperative tumor residue. To achieve this goal, the surgical treatment may include resection of the tumor invaded organs within the complex resections for ovarian cancer. Surgery was considered optimal if the residual tumor diameter was less than $1 \mathrm{~cm}$ and suboptimal if it was greater than $1 \mathrm{~cm}$. Adjuvant chemotherapy treatment was given according to oncological standards for ovarian neoplasm. The followup of the patients was carried out by periodic clinical and paraclinical checks every 6 months in order to diagnose the tumor recurrence at an earlier stage.

\section{Study Design}

The patients included in the study were those with advanced stages of the disease (stages III and IV FIGO). Their clinical, pathological, radiological and therapeutic characteristics (age, antecedents and comorbidities, symptomatology at diagnosis, CA-125 value at diagnosis, imaging aspect, FIGO stage, neoadjuvant chemotherapy, histological type, tumor grading, recurrence, and degree of complexity surgery) were evaluated in the survival analysis.

\section{Statistical Analysis}

In the analysis of survival, time was defined from the time of diagnosis to the date of death by disease or the date of completion of the study (1.11.2019).

Survival curves were plotted using the Kaplan-Meier method, and statistical significance analysis was performed with Log Rank (Mantel-Cox) tests and Cox multivariate regression analysis to evaluate independent prognostic factors. Survival and median survival were calculated and survival was estimated at $6,12,24,48,60$ months. Statistical assessment was carry out by utilisation of SPSS software (version 23.0), and $\mathrm{p}<0.05$ was considered statistically significant. 


\section{Results}

At the end of the study period, 36 patients $(55.38 \%)$ were deceased. Median survival time was aproximate 58.7 months and survival rate was $46.15 \%$ at 5 years. The average age was 62.47, with limits between 40 and 85 years. There was no statistically significant difference for survival in terms of involving the age of patients in the overall survival. Neither was for the other epidemiological factors analyzed like parity status (p_value $=0.247$, Log Rank (Mantel-Cox), reproductive status (p_value $=$ 0.450, Log Rank (Mantel-Cox), gynecological surgical history (p_value $=0.083$, Log Rank (Mantel-Cox)), or comorbidities HTN (p_value $=0.937$, Log Rank (Mantel-Cox), DM (p_value $=0.290$, Log Rank (Mantel-Cox), obesity $\left(\mathrm{p} \_\right.$value $=0.959, \log \operatorname{Rank}($ Mantel-Cox $\left.)\right)$ were not proven factors associated with global survival (Table 1).

Of the 58 patients with pelvic pain as presentic complain included in the study group 30 died, and for $28(48.3 \%)$ the death was not registered until 01.11.2019, and of the 7 patients who did not complained of pain 6 died and one survived until the end of the study. Comparing the survival on the 2 lots, the statistically significant difference is obtained (p_value $=0.033744$, Log Rank (Mantel-Cox).

The 5-year survival of patients with pelvic pain at admission is $36 \%$ while for patients without pelvic pain 5-year survival is $0 \%$ (Fig. 1, Table 1).

The other symptoms presented by the patients in the group at the time of diagnosis - metrorrhagia (p_value $=0.714, \log$ Rank (Mantel-Cox), abdominal distension (p_value $=0.398$, Log Rank (Mantel-Cox)) did not cause statistically significant differences between survival curves (Table 1).

For the values of CA125 we considered for the statistical correlation: $0=\mathrm{CA} 125$ indeterminate; 1 = CA125 <100; $2=\mathrm{CA} 125$ between 100-1000 and $3=$ CA125> 1000 . Comparing the survival of the 4 groups, no statistically significant difference is obtained (p_value $=0.679$, Log Rank (Mantel-Cox) (Table 1).

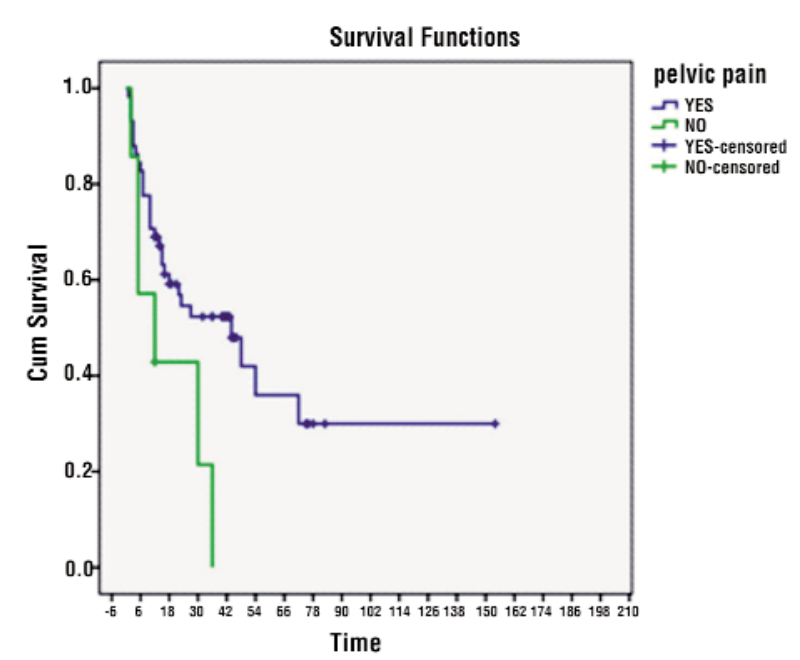

Figure 1. Kaplan Meier survival curves for pelvic pain

The imaging aspects analyzed USS/pelvis CT scan showing carcinomatosis, pelvic tumor or both (p_value $=0.250$, Log Rank (MantelCox), normal or pathological aspect of chest xray (p_value $=0.804$, Log Rank (Mantel-Cox), of plain abdominal xray (p_value $=0.782, \mathrm{Log}$ Rank (Mantel-Cox) or of the colonoscopy $\left(p \_v a l u e=0.223, \log \operatorname{Rank}(\right.$ Mantel-Cox $\left.)\right)$ did not prove factors associated with overall survival (Table 1).

Of the 39 patients in stage IIIA included in study group 19 died, and for $20(51.3 \%)$ death was recorded until 01.11.2019, and of the 4 patients in stage IIIB included in study group 3 died, and for one the death was not recorded, for the 5 patients in stage IIIC included in the study group 3 died, and for two the death was not recorded. Of the 17 stage IV patients included in the study group 11 died and 6 (35.3\%) death ws not registered. Comparing the survival of the 4 groups, we obtain a statistically significant difference (p_value = 0.026791, Breslow (Generalized Wilcoxon). We encountered significant differences between stages IIIA and IIIB (p_value $=0.007595$ ), and between stages IIIB and IIIC (p_value = 0.022090).

The 5-year survival of patients with stage FIGO IIIA is $41.4 \%$, for patients with stage FIGO IIIB is $0 \%$, for patients with stage FIGO IIIC is $0 \%$, and for patients with stage FIGO 
Table 1. Survival analysis of prognostic factors

\begin{tabular}{|c|c|c|c|c|c|c|c|}
\hline Prognostic factor & $\begin{array}{l}\text { Deceased } \\
\text { (n) }\end{array}$ & Mean - Estimate & Median - Estimate & $\begin{array}{c}\text { Five-year survival } \\
\text { rate }(\%)\end{array}$ & Univariate & Multivariate & \\
\hline & & & & p_value & HR $(95 \% \mathrm{Cl})$ & p_value & \\
\hline Age & $36 / 65$ & & & & 0.801 & & \\
\hline \multicolumn{8}{|l|}{ Parity } \\
\hline Nulipara & $23 / 31$ & 97.625 & - & $62.5 \%$ & 0.247 & & \\
\hline Multiparity & $3 / 8$ & 29.743 & 15.000 & $19.7 \%$ & & & \\
\hline \multicolumn{8}{|l|}{ Menopause } \\
\hline Yes & $34 / 59$ & 57.762 & 27.000 & $32.1 \%$ & 0.450 & & \\
\hline No & $2 / 6$ & 33.000 & 36.000 & $\operatorname{Max} 42$ & & & \\
\hline \multicolumn{8}{|l|}{ Surgical $h / x$} \\
\hline Yes & $3 / 11$ & 56.455 & - & $72.7 \%$ & 0.083 & & \\
\hline No & $32 / 53$ & 48.963 & 27.000 & $25.1 \%$ & & & \\
\hline \multicolumn{8}{|l|}{ HTN } \\
\hline Yes & $19 / 34$ & 40.527 & 30.000 & $34.4 \%$ & 0.937 & & \\
\hline No & $17 / 31$ & 60.095 & 27.000 & $30.2 \%$ & & & \\
\hline \multicolumn{8}{|l|}{ DM } \\
\hline Yes & $4 / 6$ & 19.333 & 12.000 & $\operatorname{Max} 40$ & 0.290 & & \\
\hline No & $32 / 59$ & 60.565 & 36.000 & $33.4 \%$ & & & \\
\hline \multicolumn{8}{|l|}{ Obesity } \\
\hline Yes & 2/4 & 24.250 & 30.000 & - & 0.959 & & \\
\hline No & $34 / 60$ & 57.782 & 27.000 & $31.8 \%$ & & & \\
\hline \multicolumn{8}{|l|}{ Pelvic pain } \\
\hline Yes & $30 / 58$ & 63.475 & 44.000 & $36.0 \%$ & 0.033744 & - & - \\
\hline No $=$ Ref & $6 / 7$ & 17.571 & 12.000 & - & & & \\
\hline \multicolumn{8}{|l|}{ Methroragy } \\
\hline Yes & $3 / 7$ & 26.643 & - & $\operatorname{Max} 41$ & 0.714 & & \\
\hline No & $33 / 58$ & 57.849 & 30.000 & $31.6 \%$ & & & \\
\hline \multicolumn{8}{|l|}{ Abd distension } \\
\hline yes & $6 / 9$ & 23.000 & 18.000 & $\operatorname{Max} 45$ & 0.398 & & \\
\hline No & $30 / 56$ & 61.112 & 36.000 & $34.0 \%$ & & & \\
\hline \multicolumn{8}{|l|}{ CA125 } \\
\hline 0 & $26 / 47$ & 54.292 & 27.000 & $34.6 \%$ & 0.679 & & \\
\hline 1 & $3 / 5$ & 34.000 & 48.000 & $0.0 \%$ & & & \\
\hline 2 & $4 / 8$ & 48.250 & 54.000 & $46.9 \%$ & & & \\
\hline 3 & $2 / 3$ & 20.333 & 15.000 & $\operatorname{Max} 36$ & & & \\
\hline \multicolumn{8}{|l|}{ Aspects Carcinomatosis } \\
\hline Ref & $8 / 13$ & 28.031 & 15.000 & $24.6 \%$ & & - & - \\
\hline T pelvina & $12 / 2$ & 68.343 & 48.000 & $41.6 \%$ & 0.250 & & \\
\hline T pelvina, carcinomat & $2 / 2$ & 16.000 & 10.000 & - & & & \\
\hline \multicolumn{8}{|l|}{ Pulm mets } \\
\hline Yes & $2 / 3$ & 29.333 & 10.000 & $33.3 \%$ & 0.804 & & \\
\hline No & $34 / 62$ & 56.941 & 30.000 & $30.8 \%$ & & & \\
\hline \multicolumn{8}{|l|}{ Abd Xray } \\
\hline $\mathrm{Da}$ & $2 / 3$ & 53.667 & 5.000 & $33.3 \%$ & 0.782 & & \\
\hline $\mathrm{Nu}$ & $1 / 2$ & 8.500 & 3.000 & - & & & \\
\hline \multicolumn{8}{|l|}{ Colonoscopy } \\
\hline Yes & $2 / 6$ & 19.143 & 12.000 & $\operatorname{Max} 41$ & 0.223 & & \\
\hline No & $5 / 7$ & 33.125 & - & $\operatorname{Max} 45$ & & & \\
\hline \multicolumn{8}{|l|}{ FIGO } \\
\hline IIIA & $19 / 39$ & 68.804 & 44.000 & $41.45 \%$ & & - & - \\
\hline IIIB & $3 / 4$ & 6.750 & 6.000 & - & & & \\
\hline IIIC & $3 / 5$ & 37.750 & 27.000 & $0.0 \%$ & 0.026791 & & \\
\hline IV & $11 / 17$ & 32.235 & 12.000 & $33.6 \%$ & & & \\
\hline \multicolumn{8}{|l|}{ Pathol preop exam } \\
\hline Cytologic & $7 / 12$ & 24.250 & 14.000 & $\operatorname{Max} 46$ & 0.271 & & \\
\hline Tum biopsy & $7 / 9$ & 14.259 & 5.000 & $\operatorname{Max} 36$ & & & \\
\hline Neoadjuvant treatment & & & & & & & \\
\hline Yes & $11 / 19$ & 68.598 & 22.000 & $40.2 \%$ & 0.625 & & \\
\hline No & $24 / 45$ & 41.345 & 44.000 & $33.0 \%$ & & & \\
\hline
\end{tabular}




\begin{tabular}{|c|c|c|c|c|c|c|c|}
\hline \multirow[t]{2}{*}{ Prognostic factor } & \multirow{2}{*}{$\begin{array}{l}\text { Deceased } \\
\text { (n) }\end{array}$} & \multirow[t]{2}{*}{ Mean - Estimate } & \multirow[t]{2}{*}{ Median - Estimate } & \multirow{2}{*}{$\begin{array}{c}\text { Five-year survival } \\
\text { rate (\%) }\end{array}$} & \multirow{2}{*}{$\begin{array}{c}\text { Univariate } \\
\text { p_value }\end{array}$} & \multicolumn{2}{|c|}{ Multivariate } \\
\hline & & & & & & HR $(95 \%$ Cl) & p_value \\
\hline Cytoreduction & & & & & & 0.346 & 0.021219 \\
\hline Optimal & $7 / 21$ & 81.528 & 72.000 & $68.9 \%$ & 0.035554 & $(0.140,0.853)$ & \\
\hline Subop $=$ Ref & $29 / 44$ & 32.742 & 18.000 & $21.7 \%$ & & & \\
\hline \multicolumn{8}{|l|}{ Complex Op } \\
\hline Yes & $10 / 17$ & 34.545 & 36.000 & $21.2 \%$ & 0.772 & & \\
\hline No & $26 / 48$ & 61.474 & 27.000 & $36.3 \%$ & & & \\
\hline \multicolumn{8}{|l|}{ Morbidity } \\
\hline Yes & $1 / 1$ & 2.000 & 2.000 & $0.0 \%$ & 0.000685 & 53.751 & 0.001389 \\
\hline No & $35 / 64$ & 59.584 & 30.000 & $32.8 \%$ & & $(4.672,618.365)$ & \\
\hline Pathologic type & & & & & & - & - \\
\hline Clear cells $=$ Ref & $1 / 1$ & & & $0.0 \%$ & & & \\
\hline Endometrioid & $1 / 1$ & & & $0.0 \%$ & & & \\
\hline Granulous & $0 / 1$ & & & - & 0.014835 & & \\
\hline Mucinous & $0 / 5$ & & & $\operatorname{Max} 45$ & & & \\
\hline Undifferentiate & $5 / 9$ & & & Max 43 & & & \\
\hline Serous & $24 / 41$ & & & $26.4 \%$ & & & \\
\hline \multicolumn{8}{|l|}{ Grading } \\
\hline 1 & $3 / 6$ & 46.333 & 12.000 & $50.0 \%$ & 0.963 & & \\
\hline 2 & $5 / 6$ & 32.167 & 16.000 & $16.7 \%$ & & & \\
\hline 3 & $21 / 37$ & 35.217 & 30.000 & $24.2 \%$ & & & \\
\hline \multicolumn{8}{|l|}{ P0 Treatment } \\
\hline Yes & $32 / 59$ & 59.962 & 36.000 & $32.8 \%$ & 0.000083 & 0.046 & 0.000492 \\
\hline $\mathrm{No}=\mathrm{Ref}$ & $2 / 2$ & 2.500 & 2.000 & $0.0 \%$ & & $(0.008,0.261)$ & \\
\hline \multicolumn{8}{|l|}{ Recurrence } \\
\hline Yes & $29 / 53$ & 37.483 & 27.000 & $28.9 \%$ & 0.945 & & \\
\hline No & $7 / 12$ & 67.917 & 30.000 & $38.1 \%$ & & & \\
\hline
\end{tabular}

IV is $33.6 \%$ (Fig. 2, Table 1).

Comparing the survival on the 2 groups of patients those with preoperative diagnosis of ovarian cancer established by cytological analysis of ascites fluid obtained by paracen-

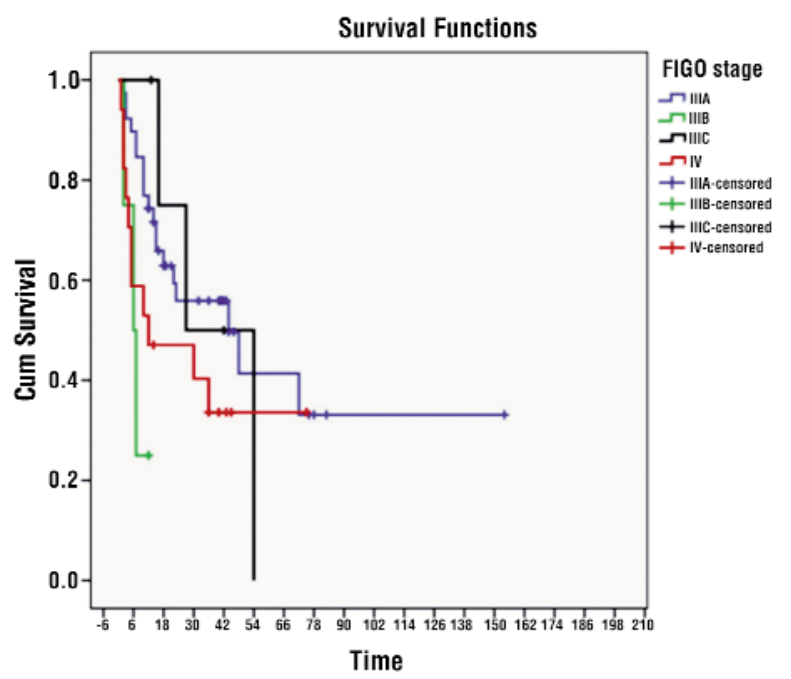

Figure 2. Survival curves Kaplan Meier test according to FIGO stage tesis and those with preoperative diagnosis of ovarian cancer obtained by histopathological examination of the peritoneal or omental biopsy during the exploratory laparotomy no statistically significant difference is noted (p_value $=0.271$, Log Rank (Mantel-Cox) (Table 1).

Of the 19 patients with neoadjuvant chemotherapy treatment included in the study group 11 died and 8 (42.1\%) survived until 01.11.2019. For the 45 patients with initial surgical resection in group 24 died and for $21(46.7 \%)$ death was not recorded until the end of the study. Comparing the survival on the 2 groups, no statistically significant difference is obtained (p_value $=0.625, \log$ Rank (Mantel-Cox) (Table 1).

Of the 21 patients with optimal resections included in the study group 7 died, and for 14 (66.7\%) survived until 01.11.2019, and of the 44 patients with suboptimal resections in the group 29 of them died, and for 15 (34.1\%) patients death was recorded until the end of the study. Comparing the survival on the 2 
lots, statistically significant difference is observed ( $\mathrm{p}$ _value $=0.035554$, Log Rank (Mantel-Cox).

The 5-year survival of patients with optimal cytoreduction is $68.9 \%$, and for patients with suboptimal cytoreduction it is 21.7\% (Fig. 3, Table 1).

Comparing the survival of the 2 groups of patients with complex resections and those without complex resections, no statistically significant difference is obtained (p_value = 0.772, Log Rank (Mantel-Cox) (Table 1).

Of the 64 patients without post-operative complications included in the study group, 35 died, and for 29 (45.3\%) death was not recorded until 01.11.2019. Comparing the survival on the 2 lots, statistically significant difference is obtained (p_value $=0.000685$, Log Rank (Mantel-Cox).

The 5-year survival rate of patients without postoperative complications is $32.8 \%$, and for patients with postoperative complications it is 0\% (Fig. 4, Table 1).

One patient with clear cell carcinoma included in the study group died, as did the patient with endometrioid carcinoma, for the patient with granulous and for the 5 patients with mucinous carcinomas the death was not registered until 01.11 .2019. For the 9 patients with undifferentiated carcinomas from group 5 died, and for the 41 patients with serous carcinomas 17 of them were still surviving at the end of the study. Comparing the survival on the 5 lots, we obtain a statistically significant difference (p_value $=0.014835$, Log Rank (Mantel-Cox).We found significant differences on survival between patients with clear cell carcinomas and those with mucinous tumor type $\left(\mathrm{p} \_\right.$value $=0.025347$ ), between patients with clear cell carcinomas and those with serous carcinomas ( $p_{\text {_value }}=0.003063$ ), between endometrioid and mucinous type (p_value $=0.025347)$ and between mucinous and serous types (p_value $=0.046266$ ).

Survival analysis shows different survival curves and that the mucinous type carcinoma has led to the best survival rate: $100 \%$ at 36 months with a maximum of $45 \%$ at 5 years, while clear cell and endometroid carcinoma

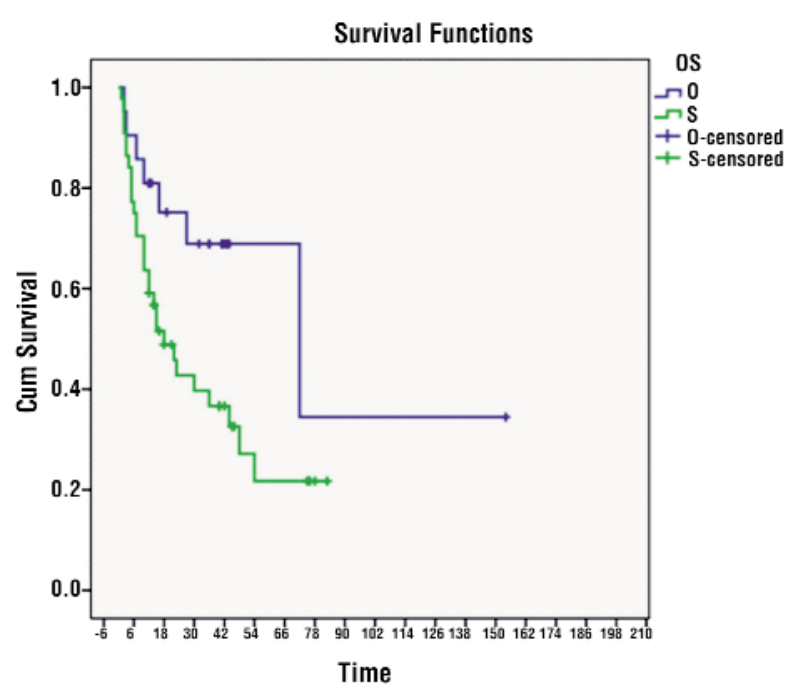

Figure 3. Kaplan Meier survival curves based on the type of citoreduction

recorded the lowest survival rate of $0 \%$ at 5 years. Intermediate curves were observed for undifferentiated tumors with a 5-year survival rate of maximum $43 \%$, and for the case of serous tumors of $26.4 \%$ (Fig. 5, Table 1).

Comparing the survival on the 3 groups of patients with well differentiated tumors G1, medium differentiated G2 and poorly differentiated G3, no statistically significant difference is obtained ( $\mathrm{p}$ _value $=0.963, \mathrm{Log}$ Rank (Mantel-Cox) (Table 1).

Of the 59 patients with adjuvant chemo-

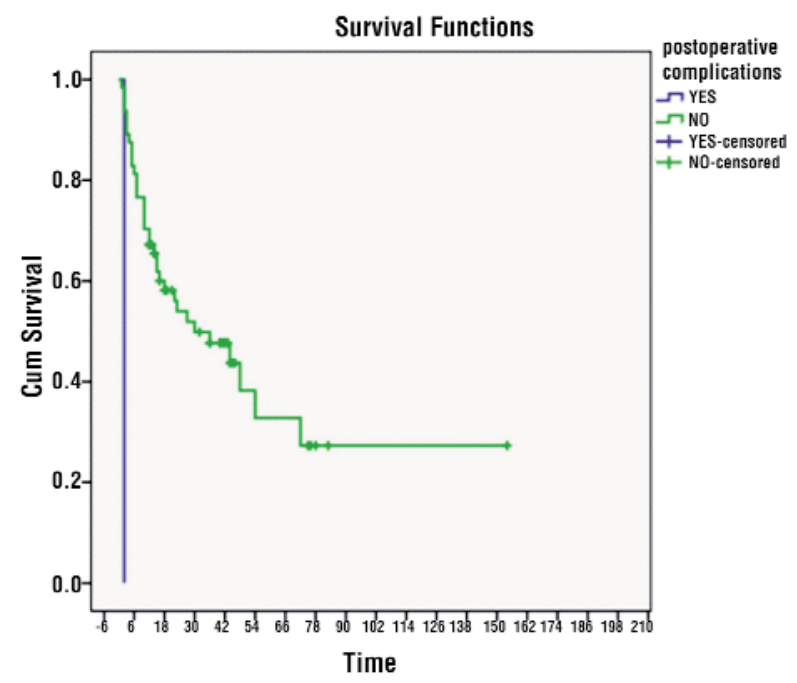

Figure 4. Kaplan Meier survival curves for presence of postoperative complications 


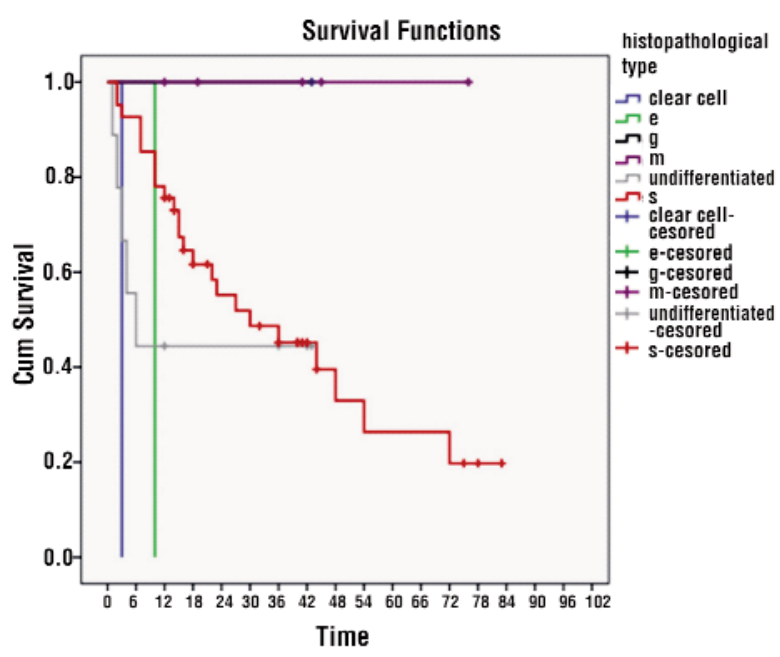

Figure 5. Kaplan Meier survival curves according to histopathological type

therapy for ovarian cancer included in the study group 32 died and for 27 (45.8\%) death was not registered until 01.11.2019. For the 2 patients without adjuvant chemotherapy in the group, both died until the end of the study. Comparing the survival on the 2 lots, the statistically significant difference is obtained $\left(p_{\text {_value }}=0.000083\right.$, Log Rank (Mantel-Cox $)$.

The 5-year survival of patients with adjuvant chemotherapy is $32.8 \%$, and for patients without adjuvant chemotherapy it is $0 \%$ (Fig. 6, Table 1).

Comparing the survival on the 2 groups of patients those who had tumor recurrence and those without recurrence during the follow-up period, no statistically significant difference is obtained ( $p \_$value $=0.945$, Log Rank (MantelCox) (Table 1).

Comparing survival in patients without postoperative complications with those who had postoperative complications, the chances/ risk of death for cases with postoperative complications were calculated $-\mathrm{HR}=53,751,95 \%$ $\mathrm{CI}=(4,672,618,365) \quad\left(\mathrm{p} \_\right.$value $\left.=0.001389\right)$ (Table 1) - the presence of postoperative complications is an independent risk factor.

Comparing survival in patients with suboptimal cytoreduction with those with optimal cytoreduction, the odds/risk of death were calculated $-\mathrm{HR}=0.346,95 \% \mathrm{CI}=(0.140$,

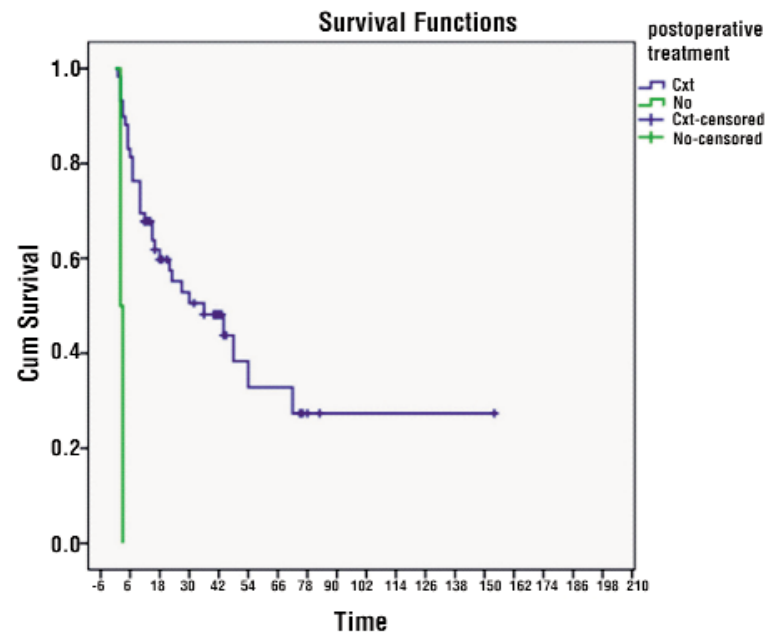

Figure 6. Kaplan Meier survival curves according to the postoperative chemotherapy treatment

0.853), (p_value $=0.021219)($ Table 1) Optimal cytoreduction is an independent protective factor

Comparing survival in patients with adjuvant chemotherapy with those without postoperative treatment, the odds/risk of death for patients with adjuvant treatment were calculated - $\mathrm{HR}=0.046,95 \% \mathrm{CI}=$ $(0.008,0.261),\left(p \_v a l u e=0.000492\right)($ Table 1$)$ Postoperative chemotherapy treatment is an independent protective factor.

\section{Discussions}

In this study, we analyzed the clinicopathological characteristics and survival outcomes of ovarian cancer patients treated at Sf.Maria Hospital between 2010-2018. We found that the epidemiological factors: nulliparous status, reproductive status, gynecological surgical history, history of high blood pressure, diabetes, obesity; clinico-paraclinic factors: metrorrhagia, abdominal distension, level of CA125 marker at admission, chest Xray or abdominal Xray; the colonoscopic aspect; the therapeutic factors: neoadjuvant chemotherapy were not risk factors for the overall survival. While the clinical-paraclinical factors like pelvic pain, FIGO stage and therapeutic ones like type of optimal/sub- 
optimal resection, postoperative complications, adjuvant chemotherapy, pathological type has been prooved to be prognostic factors for long-term survival.

Ovarian tumors is the leading cause of death from malignancy disease for women and is the $4^{\text {th }}$ on mortality among women. Databases and reports from 2019 show that the estimated number of new cases is 22240 , and the number of deaths around 14170 cases (16). In Romania, the incidence of ovarian cancer has been stable in recent years, according to Globocan (6, 3/100 000 in 2008 and 6.1/100,000 in 2012) (17.18), and mortality was among the five main causes of cancer deaths (19). The highest incidence of ovarian tumors in the batch analysed was in the age interval of 60 and 69, which keeps in line with data from the literature (20). In our study, the age of the patients included in the lot was not demonstrated to have significant statistical power for survival rate, unlike other studies, which verified that the age is an independent prognostic variable in patients with advanced ovarian cancer (21-23).

The majority of females in our study were multiparous, and the 5-year survival rate was $19.7 \%$. Although the nulliparous patients had a much better 5-year survival (62.5\%), the difference was not statistically significant, unlike other studies in the literature, which obtained for the nulliparous patients a survival at 5 years similar (61.1\%) but demonstrated statistical significance compared to the multiparous patients (24).

Obesity and lack of physical activity are associated with increased mortality from ovarian cancer (25). Excessive weight and increased fat deposits, that comes with weight gain, have been shown to promote tumor progression by producing growth factor I - insulin like and hyperinsulinemia (26) and by promoting chronic inflammation by increasing CRP level and tumor necrosis factor alpha. (27) Obese women with ovarian cancer receive less aggressive treatment to avoid adverse reactions. (28) Obesity has not been shown in our group. risk to global survival. And other studies emphasize that the combination between high BMI and survival of patients with ovarian tumors remains unambiguous and that the body mass index at the time of diagnosis cannot be a prognostic factor for these patients (29).

In our study, FIGO stage proved it's relevance in prognosis, but not an an independent factor, as other authors have demonstrated $(8,30)$. More than half of the patients were diagnosed in stage IIIA FIGO, where the five-year survival was only $41.4 \%$, this stage causing a statistically significant difference from the stage IIIB. The small number of patients in stage IIIC is a possible explanation for the lower survival of these patients $(0 \%)$ compared to those in stage IV (33.6\%).

Some recent studies dispute that there is still not enough evidence that neoadjuvant chemotherapy followed by citoreduction is superior to the primary surgical approach. They recommended that clinical background, tumor type, and the response to chemotherapy should be considered for individualization of treatment: nonserous tumors (type 1) with a favorable prognosis are in fact less chemosensitive, and the omission of neadjuvant treatment with primary cytoreduction would have better results, and for patients with high stage serous ovarian tumors (type 2) with severe illnesses or poor performance, the authors recommend neoadjuvant treatment first followed by interval cytoreduction. (31). For the patients included in the study, these recommendations were not applied, surgical treatment was the first line, and when it was not possible patient followed neoadjuvant chemotherapy and then interval surgery. From the statistical analysis, administration of neoadjuvant therapy has not been demonstrated to be a prognostic factor for long-term survival.

The most common histopathological type found in the study group was serous cancer (71\%), with five year survival of $26.4 \%$, turning out to be statistically significant in terms of survival compared to the type of clear cell carcinoma or serous tumors. For the patients with mucinous type tumors, we found the best survival rate of $100 \%$ at 36 months 
with a maximum survival at 5 years of $45 \%$. Other authors report a mortality rate of about $50 \%$ for mucinous tumors and 34\% for clear cell tumors (13). Other studyes reported that the pathological type influences statistically significant the survival, highlighting that endometrioid and serous tumors have a better prognosis than clear cell carcinoma and mucinous types (21).

Our results came to the conclusion that poorly differentiated (G3) tumors were most frequently identified (75.5\%), with a 5-year survival of $24.2 \%$ comparable to that obtained in other studies (23.5\%) (24). Univariate analysis showed that grading was not statistically relevant, compared to data from other studies who identified poorly differentiated tumors as a prognostic factor $(24,32)$.

Since 1968, some authors have observed that in patients with ovarian cancer the prognosis was most severe if the residual disease was $>1.5 \mathrm{~cm}$ (33). In 1975, other authors found that in patients with residual disease $\leq 1.5 \mathrm{~cm}$, survival improved as the size of the tumor decreased. Survival time was 39, 29, 18 and 11 months for patients with residual disease from $0 \mathrm{~cm}$ to $<0.5 \mathrm{~cm}, 0.6-1$ $\mathrm{cm}, 1.1-1.5 \mathrm{~cm}$, respectively $>1,5 \mathrm{~cm}$ (8). These aspects were supported by the results of subsequent studies that found that a "definitive citoreduction" before chemotherapy resulted in improved survival compared to "partial removal" or " biopsy only" (34).

Another study that included patients with advanced stages of the disease, (35) and two other studies $(37,38)$ showed that suboptimal cytoreduction resulted in survival as low as for exploratory laparotomy. More and more authors agree that cytoreduction is very important cand influences the outcome of surgery. According to the GOG guidelines of $2001 / 2002$, the main target of all surgical procedures is to completly resect the tumour (total cytoreduction) or resection with residual mass of less than $1 \mathrm{~cm}$ (optimal cytoreduction). In our study, approximately one third of patients underwent optimal cytoreduction with a 5-year survival of $68.9 \%$, which was validated as an valid prognostic factor in univariate analysis $(\mathrm{p}<0.05)$, while the multivariate analysis validated suboptimal cytoreduction as an independent factor. Such data have also been reported by other studies of patients with advanced ovarian cancer (23). A 2002 meta-analysis of 6885 patients with stage III and IV ovarian cancer compared multiple determinants for survival, concluding that total cytoreduction influences the median survival curve (39). Some reports state that the target of surgery for cytoreduction for ovarian tumors should aim for a complete resection $(7,40,41)$. For our patients with optimal cytoreduction, the estimated median survival time was 72 months. Other studies report median survival of 99 months (42) and 106 months (41), which is achivable for those patients that underwent complete resection. Other published endorsements show a survival of only $23.8 \%$ reported after surgery that failed to achive optimal cytoreduction (23), close to the $21.7 \%$ survival obtained in our group in patients with suboptimal cytoreduction.

In our study, $97 \%$ of patients received chemotherapy after recover from surgery, with paclitaxel/carboplatin as first-line chemo-therapy with a 5-year survival of $32.8 \%$. The univariate analysis showed that survival was statistically significantly better in patients who received postoperative polychromy than those who did not receive chemotherapy, proving to be an independent prognostic factor in multivariate analysis, as opposed to another study that reported a survival. at 5 years of $46 \%$ in patients who received chemotherapy schemes similar to those in our study, this did not prove statistically different from that of patients who did not undergo postoperative chemotherapy (27). Research identified that multiple lines of chemtherapy prooved to be statistically valid only in conjunction with optimal resection. According to data from a study, the best survival rate was achived in patients that followed chemotherapy after being treated by surgery with complete resection (40). 


\section{Conclusions}

1. Epidemiological factors: parity status, reproductive status, gynecological surgical history, history of HTN, DM, obesity; clinical and paraclinical factors: metrorrhagia or abdominal distension at the time of diagnosis, high level of tumor marker CA125; aspect of chest xray or abdominal xray, colonoscopy findings and therapeutic factors: neoadjuvant chemotherapy, were not prognostic factors for overall survival.

2. The following clinical and paraclinical factors: absence of pelvic pain at the time of diagnosis, stage FIGO IIIC; treatment type: suboptimal citoreduction, postoperative morbidity, absence of adjuvant treatment and histopathological type of clear cell cancer have been shown to be prognostic factors global survival.

3. For patients with ovarian cancer, optimal cytoreduction and administration of adjuvant chemotherapy are independent protective factors for longterm survival, and the presence of post-operative complications has been shown to be an independent risk factor.

\section{Conflict of Interest}

The authors declare no conflicts of interests.

\section{References}

1. Cadariu PA, Bacalbasa N, Blidaru A eds. Tratat de chirurgie extrapelvina a cancerului de ovar. Bucuresti: Ed. Universitara Carol Davila; 2017, capitolul 7, pag. 122.

2. Hoppenot C, Eckert MA, Tienda SM, Lengyel E. Who are the long-term survivors of high grade serous ovarian cancer? Gynecol Oncol. 2018;148(1):204-212.

3. Eisenhauer EA Real-world evidence in the treatment of ovarian cancer. Ann Oncol. 2017;28(suppl_8):viii61-viii65.

4. Beral V, Doll R, Hermon C, Peto R, Reeves G Ovarian cancer and oral contraceptives: collaborative reanalysis of data from 45 epidemiological studies including 23.257 women with ovarian cancer and 87.303 controls. Lancet 2008; 371: 303-314.

5. https://seer.cancer.gov/statfacts/html/ovary.html (11 september 2017, date last accessed)

6. Tretarre B, Molinie F, Woronoff AS, Bossard N, Bessaoud F, Marrer $\mathrm{E}$, et al. Ovarian cancer in France; trends in incidence, mortality and survival, 1980-2012. Gynecol Oncol. 2015;139(2):324-329.
7. Eisenkop SM, Friedman RL, Wang HJ: Complete cytoreductive surgery is feasible and maximizes survival in patients with advanced epithelial ovarian cancer: Gynecol Oncol. 1998;69:103-108.

8. Griffiths CT: Surgical resection of tumor bulk in the primary treatment of ovarian carcinoma. Natl Cancer Inst Monogr. 1975;42: 101-104.

9. Rauh-Hain JA, Melamed A, Wright A, Gockley A, Clemmer JT, Schorge JO, et al. Overall survival following neoadjuvant chemotherapy vs primary cytoreductive surgery in women with epithelial ovarian cancer: analysis of the National Cancer database JAMA Oncol. 2017:3:76-82.

10. Lee YJ, Chung YS, Lee JY, Nam EJ, Kim SW, Kim S, Kim YT. Impact of increased utilization of neoadjuvant chemotherapy on survival in patients with advanced ovarian cancer: experience from a comprehensive cancer center. J Gynecol Oncol. 2018;29(4):e63.

11. Wright AA, Cronin A, Milne DE, Bookman MA, Burger RA, Cohn DE et al. Use and efectiveness of intraperitoneal chemotherapy for treatment of ovarian cancer. J Clon Oncol. 2015;33:2841-2847.

12. Baek MH, Kim DY, Kim SO, Kim YJ, Park YH. Impact of beta blockers on survival outcomes in ovarian cancer: a nationwide populationbased cohort study. J Gynecol Oncol. 2018;29(6):e82.

13. Johnson CT, Hallok JL, Bienstock JL, Fox HE, Wallach EE. The Johns Hopkins Manual of Gynecology and Obstetrics, 5th editon. Ed. Wolters Kluwer. 2015

14. Zhong Q, Peng HL, Zhao X, Zhang L, Hwang WT.Effects of BRCA1and BRCA2-related mutations on ovarian and breast cancer survival: a meta-analysis. Clin Cancer Res. 2015;21(1):211-20.

15. Booth CM, Tannock I. Randomised controlled trials and population - based observational research: partners in the evolution of medical evidence. Br J Cancer. 2014:110:551-555.

16. DeSantis CE, Miller KD, Dale W, Mohile SG, Cohen HJ, Leach CR, et al. Cancer statistics for adults aged 85 years and older. CA Cancer J Clin. 2019;69(6):452-467.

17. Ferlay J, Shin HR, Bray F, Forman D, Mathers C, Parkin DM. Estimates of worldwide burden of cancer in 2008: GLOBOCAN 2008. Int J Cancer 2010;127:2893-917.

18. Ferlay J, Soerjomataram I, Dikshit R, Eser S, Mathers C, Rebelo M et al. Cancer incidence and mortality worldwide: sources, methods and major patterns in GLOBOCAN 2012. Int J Cancer. 2015; 136:E359-86.

19. Coza D, Suteu O, Nicula FA. Cancer report in north-western region of Romania 2010-2011: cancer incidence, mortality, survival, and prevalence. ClujNapoca: Casa Cartii de Stiinta; 2014.

20. Edmonds K. Dewhurst's Textbook of Obstetrics and Gynaecology. 8th edn. Hoboken, NJ: John Wiley and Sons Ltd., 2012.

21. Makar AP, Baekelandt M, Tropé C, Kristensen G. The prognostic significance of residual disease, FIGO substage, tumor histology, and grade in patients with FIGO stage III ovarian cancer. Gynecol Oncol.1995;56:175-80.

22. Chi DS, Liao JB, Leon LF, Venkatraman ES, Hensley ML, Bhaskaran $\mathrm{D}$, et al. Identification of prognostic factors in advanced epithelial ovarian carcinoma. Gynecol Oncol.2001:82:532-7.

23. Li X, Du X. Neoadjuvant chemotherapy combined with interval cytoreductive surgery in ovarian cancer. JBUON. 2019; 24(5): 2035-2040

24. Topolovec Z, Horvat T, Vidosavljević D, Šijanović S, Müller-Vranješ A, Ugljarević M, et al. Prognostic significance of Cytoreductive Therapy of Ovarian Cancer - eastern Croatia experience. Acta Clin Croat. 2019;58(2):311-320

25. Minlikeeva AN, Cannioto R, Jensen A, Kjaer SK, Jordan SJ, Diergaarde B, et al. Ovarian Cancer Association Consortium. Joint exposure to smoking, excessive weight, and physical inactivity and survival of ovarian cancer patients, evidence from the Ovarian Cancer Association Consortium. Cancer Causes Control. 2019; 30(5):537-547.

26. Calle EE, Kaaks R. Overweight, obesity and cancer: epidemiological evidence and proposed mechanisms. Nat Rev Cancer 2004; 
$4(8): 579-91$.

27. Renehan AG, Zwahlen M, Egger M. Adiposity and cancer risk: new mechanistic insights from epidemiology. Nat Rev Cancer. 2015; 15(8):484-98

28. Au-Yeung G, Webb PM, DeFazio A, Fereday S, Bressel M, Mileshkin L. Impact of obesity on chemotherapy dosing for women with advanced stage serous ovarian cancer in the Australian Ovarian Cancer Study (AOCS). Gynecol Oncol 2014;133(1):16-22.

29. Bae HS, Kim HJ, Hong JH, Lee JK, Lee NW, Song JY Obesity and epithelial ovarian cancer survival: a systematic review and meta-analysis. J Ovarian Res. 2014;7:41.

30. Hornung R, Urs E, Serenella E, Edward W, Ursula S, Urs H, et al. Analysis of potential prognostic factors in 111 patients with ovarian cancer. Cancer Lett. 2004;206:97-106.

31. Makar AP, Tropé CG, Tummers P, Denys H, Vandecasteele K Advanced Ovarian Cancer: Primary or Interval Debulking? Five Categories of Patients in View of the Results of Randomized Trials and Tumor Biology: Primary Debulking Surgery and Interval Debulking Surgery for Advanced Ovarian Cancer. Oncologist. 2016; 21(6):745-54

33. Munnell EW. The changing prognosis and treatment in cancer of the ovary. A report of 235 patients with primary ovarian carcinoma 1952-1961. Am J Obstet Gynecol. 1968;100:790-805.

34. Chi DS, Liao JB, Leon LF, Venkatraman ES, Hensley ML, Bhaskaran $D$ et al. Identification of prognostic factors in advanced epithelial ovarian carcinoma. Gynecol Oncol. 2001:82:532-7.

35. Heintz AP, Van Oosterom AT, Trimbos JB, Schaberg A, Van der Velde EA, Nooy M The treatment of advanced ovarian carcinoma (I): Clinical variables associated with prognosis. Gynecol Oncol.1988; 30: 347-358.
36. Bertelsen K. Tumor reduction surgery and long-term survival in advanced ovarian cancer: A DACOVA study. Gynecol Oncol.1990; 38:203-209.

37. Webb MJ. Cytoreduction in ovarian cancer: Achievability and results. Baillieres Clin Obstet Gynaecol.1989;3:83-94.

38. Hoskins WJ, Bundy BN, Thigpen JT, Omura GA The influence of cytoreductive surgery on recurrence-free interval and survival in small-volume stage III epithelial ovarian cancer: A Gynecologic Oncology Group study. Gynecol Oncol.1992;47:159-166.

39. Bristow RE, Tomacruz RS, Armstrong DK, Trimble EL, Montz FJ Survival effect of maximal cytoreductive surgery for advanced ovarian carcinoma during the platinum era: a meta-analysis. J Clin Oncol. 2002;20:1248-59.

40. Eisenhauer EL, Abu-Rustum NR, Sonoda Y, Aghajanian C, Barakat RR, Chi DS. The effect of maximal surgical cytoreduction on sensitivity to platinum-taxane chemotherapy and subsequent survival in patients with advanced ovarian cancer. Gynecol Oncol. 2008;108: $276-81$.

41. Chi DS, Eisenhauer EL, Lang J, Huh J, Haddad L, Abu-Rustum NR. What is the optimal goal of primary cytoreductive surgery for bulky stage IIIC epithelial ovarian carcinoma? Gynecol Oncol. 2006;103: 559-64.

42. du Bois A, Reuss A, Pujade-Lauraine E, Harter P, Ray-Coquard I, Pfisterer J. Role of surgical outcome as prognostic factor in advanced epithelial ovarian cancer: a combined exploratory analysis of 3 prospectively randomized phase 3 multicenter trials: by the Arbeitsgemeinschaft Gynaekologische Onkologie Studiengruppe Ovarialkarzinom (AGO-OVAR) and the Groupe d'Investigateurs Nationaux Pour les Etudes des Cancers de l'Ovaire (GINECO). Cancer. 2009;115:1234-44. 